\title{
Ice-Nucleating Active Bacteria Decrease the Cold-Hardiness of Stored Grain Insects
}

\author{
RICHARD E. LEE, JR., JANET M. STRONG-GUNDERSON, MARCIA R. LEE, ${ }^{1}$ \\ AND EVELYN C. DAVIDSON \\ Department of Zoology, Miami University, \\ Oxford, Ohio 45056
}

\begin{abstract}
J. Econ. Entomol. 85(2): 371-374 (1992)
ABSTRACT This report provides further evidence that a freeze-dried, concentrated form of Pseudomonas syringae, an ice-nucleating active bacteria, reduces the cold tolerance of stored grain insect pests. Application of ice-nucleating bacteria to wheat or corn that contained insect pests decreased the insects' supercooling capacity: after treatment with $100 \mathrm{ppm}$ of $P$. syringae the mean supercooling points of five insect species increased from 4.7 to $11.9^{\circ} \mathrm{C}$ above untreated controls. Treatment with $P$. syringae also decreased the capacity of insects to survive a 24 -h exposure to subzero temperatures. Decreases in cold tolerance were observed in eight species of stored grain pests: Indianmeal moth larvae, Plodia interpunctella (Hübner); red flour beetle adults, Tribolium castaneum (Herbst); flat grain beetle adults, Cryptolestes pusillus (Schonherr); rusty grain beetle adults, Cryptolestes ferrugineus (Stephens); Gibbium psylloides (Czenpinski); lesser grain borer adults, Rhyzopertha dominica (F.); yellow mealworm larvae, Tenebrio molitor (L.); and granary weevil adults, Sitophilus granarius (L.). Results of this study provide further support for the use of ice-nucleating active bacteria as biological insecticides to kill overwintering insects by decreasing their low temperature tolerance. The approach may be particularly appropriate for the control of a variety of insect pests in restricted areas such as grain bins.
\end{abstract}

KEY WORDS Insecta, cold-hardiness, ice nucleating bacteria, biological control

A MAJOR FACTOR in the overwintering survival of insect pests is their capacity to cold-harden (see reviews in Lee \& Denlinger [1991]). Most overwintering insects are freeze-intolerant (Somme 1982). In the winter, many of these species survive by increasing their capacity to avoid freezing by supercooling, thus avoiding the lethal effects of internal ice formation (Ring 1982). Increases in supercooling capacity require the removal or inactivation of ice-nucleating catalysts (Lee 1989). Although several lines of evidence suggest that ice nucleation begins in the gut in some species, the precise nature of the heterogeneous ice-nucleating agent that regulates supercooling in freeze-intolerant insects is not clearly established (Baust \& Rojas 1985, Lee 1989, Shimada 1989).

Ice-nucleating active bacteria are the most efficient heterogeneous ice-nucleating agents known. These ubiquitous bacteria are commonly found on the surface of plants and can induce freezing of plant tissues at high subzero temperatures, and it is believed that their presence causes substantial amounts of frost-related crop losses worldwide (Lindow 1983).

\footnotetext{
${ }^{1}$ Department of Microbiology, Miami University, Oxford,
} Ohio 45056.
Ice-nucleating active bacteria can significantly decrease the supercooling capacity of insects, causing a loss of cold tolerance (Strong-Gunderson et al. 1989, 1990). Either ingestion or topical application of these bacteria to the surface of insects elevates the supercooling point the temperature at which an insect begins to freeze internally) in a variety of freeze-intolerant insects, thereby inducing mortality. Furthermore, icenucleating active bacteria are normal flora of the insect gut (Lee et al. 1991). These facts suggest that ice-nucleating active bacteria may provide a novel means of biological control for freezeintolerant insect pests during the winter (StrongGunderson et al. 1990, Lee 1991).

Fields (1991) recently demonstrated that the application of Pseudomonas syringae to the rusty grain beetle, Cryptolestes ferrugineus (Stephens), not only caused a significant increase in the supercooling point of this species, but decreased its cold-hardiness when exposed to subzero temperatures. He also proposed that icenucleating active bacteria might function as a cold synergist for the control of insects in grain bins. The study presented here extends his observations to determine the effect of $P$. syringae on the supercooling capacity and cold tolerance of a number of freeze-intolerant stored grain insects. 
Table 1. Effect of the ice-nucleating active bacteria $P$. syringae on the supercooling point of stored grain insects

\begin{tabular}{|c|c|c|c|c|}
\hline \multirow{2}{*}{ Species } & \multicolumn{2}{|c|}{ Supercooling point $\left({ }^{\circ} \mathrm{C}\right), x \pm \mathrm{SEM}$} & \multirow{2}{*}{$F$} & \multirow{2}{*}{$P$} \\
\hline & Untreated control & P. syringae $(100 \mathrm{ppm})$ & & \\
\hline P. interpunctella (larvae) & $\begin{array}{c}-10.3 \pm 0.4 \mathrm{a} \\
(n=54)\end{array}$ & $\begin{array}{c}-5.4 \pm 0.5 \mathrm{a} \\
(n=33)\end{array}$ & 91.0 & $<0.001$ \\
\hline S. granarius (adults) & $\begin{aligned} &-15.7 \pm 1.0 \mathrm{~b} \\
&(n=16)\end{aligned}$ & $\begin{array}{c}-8.0 \pm 0.6 \mathrm{~b} \\
(n=18)\end{array}$ & 41.8 & $<0.001$ \\
\hline R. dominica (adults) & $\begin{array}{c}-15.2 \pm 0.6 \mathrm{~b} \\
(n=12)\end{array}$ & $\begin{array}{c}-3.3 \pm 0.1 \mathrm{c}, \mathrm{d} \\
(n=7)\end{array}$ & 209.8 & $<0.001$ \\
\hline T. castaneum (adults) & $\begin{array}{c}-13.9 \pm 0.8 b \\
(n=23)\end{array}$ & $\begin{aligned}-4.7 & \pm 0.4 \mathrm{a}, \mathrm{d} \\
(n & =11)\end{aligned}$ & 66.3 & $<0.001$ \\
\hline G. psylloides (adults) & $\begin{array}{c}-10.7 \pm 0.9 \mathrm{a} \\
(n=11)\end{array}$ & $\begin{array}{c}-6.0 \pm 0.5 \mathrm{a} \\
(n=11)\end{array}$ & 22.1 & $<0.001$ \\
\hline
\end{tabular}

Significant differences $(P<0.05)$ using one-way ANOVA tests of supercooling point means among species for untreated control and $P$. syringae treatment are indicated by different letters.

Within-species comparisons of mean supercooling points for untreated control and $P$. syringae were compared using a two-sample, one-way ANOVA test.

\section{Materials and Methods}

Insect Cultures. Laboratory strains (in culture for at least $5 \mathrm{yr}$ ) of the Indianmeal moth, Plodia interpunctella (Hubner); red flour beetle, Tribolium castaneum (Herbst); flat grain beetle, Cryptolestes pusillus (Schonherr); rusty grain beetle, C. ferrugineus; Gibbium psylloides (Czenpinski); lesser grain borer, Rhyzopertha dominica $(\mathrm{F}$.); yellow mealworm, Tenebrio molitor (L.); and granary weevil, Sitophilus granarius (L.) were maintained at $\approx 23^{\circ} \mathrm{C}$ using standard methods (Bell 1982, Evans 1983).

Determination of Supercooling Points. Supercooling point values were determined by positioning insects in contact with a 30-gauge copper-constantan thermocouple within a $1.5-\mathrm{ml}$ polypropylene tube. These tubes were placed into glass test tubes suspended in a $0^{\circ} \mathrm{C}$ refrigerated bath and allowed to equilibrate for $5 \mathrm{~min}$ before cooling at $\approx 0.6^{\circ} \mathrm{C} / \mathrm{min}$. The lowest temperature reached before the release of the latent heat of fusion was recorded as the supercooling point.

Effect of $P$. syringae on Low Temperature Survival of Stored Grain Pests. Our source of a bacterial ice nucleator was a concentrated, freezedried, and killed preparation of $P$. syringae (Genencor International, Rochester, N.Y.). This product provides a highly efficient source of heterogeneous ice nucleators for commercial snowmaking. The $P$. syringae used in this study had an ice nucleating activity of $2.02 \times 10^{4}$ ice nucleating sites per gram. To evaluate the effect of ice-nucleating active bacteria on insect cold tolerance, 30-40 insects were added to $10 \mathrm{~g}$ of wheat inoculated with $P$. syringae and held at $23^{\circ} \mathrm{C}$ for $24 \mathrm{~h}$. Treatment doses (100 or 1,000 ppm) were based on the weight of dry, powdered $P$. syringae to weight of grain. Control insects were added to $10 \mathrm{~g}$ of wheat that did not contain $P$. syringae. The samples were subsequently transferred directly to a refrigerated bath at -5 or $-8^{\circ} \mathrm{C}$ for $24 \mathrm{~h}$. After a final $24 \mathrm{~h}$ at $23^{\circ} \mathrm{C}$, the proportion of surviving insects was determined. Survival was based on the ability of the insects to walk normally. Another similar experiment was done with corn instead of wheat.

Supercooling point values were compared using two-factor and one-factor analysis of variance (ANOVA) followed by Fisher's Least Significant Differences test to separate means (Sokal \& Rohlf 1973). Chi-square analysis was used to compare survival rates of treated insects versus controls.

\section{Results}

Supercooling Points. Five species of insects were exposed to $100 \mathrm{ppm}$ of $P$. syringae mixed with wheat for $24 \mathrm{~h}$ at $23^{\circ} \mathrm{C}$ (Table 1 ). No individual survived freezing (i.e., exposure to temperatures below its supercooling point). Using a two-factor ANOVA test, significant differences were observed among species $(F=14.7 ; \mathrm{df}=4$, 4; $P<0.001)$ and between treatments $(F=284.8$; $\mathrm{df}=1,4 ; P<0.001)$. Among species for untreated controls, mean supercooling point values were higher $(P<0.05)$ for $P$. interpunctella and $G$. psylloides than for the other three species. Mean supercooling points for untreated controls ranged between -10.3 and $-15.7^{\circ} \mathrm{C}$. In contrast, supercooling points for insects treated with icenucleating active bacteria were significantly higher $(P<0.001)$ for each species tested with values ranging between -3.3 and $-8.0^{\circ} \mathrm{C}$. The magnitude of the treatment effect ranged from a mean increase of $4.7^{\circ} \mathrm{C}$ in the supercooling point value of Indianmeal moth larvae to a maximum of an $11.9^{\circ} \mathrm{C}$ increase in lesser grain beetle adults. $R$. dominica adults treated with $P$. syringae had significantly higher $(P<0.001)$ supercooling points than the other species.

Effect of $P$. syringae on Low Temperature Survival of Stored Grain Pests. Of the untreated control insects exposed to $-5^{\circ} \mathrm{C}$ for $24 \mathrm{~h}$ in wheat, six species exhibited survival rates of $90-98 \%$ (Ta- 
Table 2. Survival of larval and adult stored grain pests exposed to various concentrations of dry, powdered $P$. syringae in wheat for $24 \mathrm{~h}$ at $23^{\circ} \mathrm{C}$ before $24-\mathrm{h}$ exposure to -5 or $-8^{\circ} \mathrm{C}$

\begin{tabular}{|c|c|c|c|c|c|c|c|c|c|}
\hline & \multicolumn{9}{|c|}{$\%$ Survival } \\
\hline & \multicolumn{5}{|c|}{$-5^{\circ} \mathrm{C}$ for $24 \mathrm{~h}$} & \multicolumn{4}{|c|}{$-8^{\circ} \mathrm{C}$ for $24 \mathrm{~h}$} \\
\hline & \multirow{2}{*}{$\begin{array}{l}\text { Untreated } \\
\text { control }\end{array}$} & \multicolumn{4}{|c|}{ P. syringae } & \multirow{2}{*}{$\begin{array}{l}\text { Untreated } \\
\text { control }\end{array}$} & \multicolumn{3}{|c|}{ P. syringae } \\
\hline & & \multicolumn{2}{|c|}{$100 \mathrm{ppm}$} & \multicolumn{2}{|c|}{$1,000 \mathrm{ppm}$} & & \multirow{2}{*}{$\frac{100 \mathrm{ppm}}{23(7 / 30)^{* *}}$} & \multicolumn{2}{|c|}{$1,000 \mathrm{ppm}$} \\
\hline T. molitor (larvae) & $97(29 / 30)$ & 77 & $(23 / 30)^{*}$ & 73 & $(22 / 30)^{*}$ & $77(23 / 30)$ & & 53 & $(16 / 30)$ \\
\hline S. granarius (adults) & $96(27 / 28)$ & 62 & $(18 / 29)^{*}$ & 48 & $(15 / 31)^{* *}$ & $84(27 / 32)$ & $23(7 / 31)^{* *}$ & 3.6 & $(1 / 28)^{* *}$ \\
\hline C. ferrugineus (adults) & $97(28 / 29)$ & 0 & $(0 / 30)^{* *}$ & 0 & $(0 / 25)^{* *}$ & $90(28 / 31)$ & $0(0 / 29)^{* *}$ & 0 & $(0 / 25)^{* *}$ \\
\hline$P$. interpunctella (larvae) & $96(23 / 24)$ & 36 & $(10 / 28)^{* *}$ & 3.8 & $(1 / 26)^{* *}$ & $67(20 / 30)$ & $0(0 / 27)^{* *}$ & 0 & $(0 / 30)^{* *}$ \\
\hline C. pusillus (adults) & $43(13 / 30)$ & 0 & $(0 / 29)^{* *}$ & 0 & $(0.20)^{* *}$ & $0(0 / 48)$ & $0(0 / 30)$ & 0 & $(0 / 29)$ \\
\hline T. castaneum (adults) & $19(6 / 31)$ & 0 & $(0 / 29)$ & 0 & $(0 / 30)$ & $0 \quad(0 / 31)$ & $0(0 / 31)$ & 0 & $(0 / 30)$ \\
\hline R. dominica (adults) & $90(27 / 30)$ & 3.6 & $(1 / 28)^{* *}$ & 0 & $(0 / 31)^{* *}$ & $0 \quad(0 / 31)$ & $0(0 / 30)$ & 0 & $(0 / 30)$ \\
\hline G. psylloides (adults) & $93(28 / 30)$ & 25 & $(8 / 32)^{* *}$ & 0 & $(0 / 30)^{* *}$ & $53(16 / 30)$ & $0(0 / 30)^{* *}$ & 0 & $(0 / 31)^{* *}$ \\
\hline
\end{tabular}

Numbers in parentheses indicate the number of survivors/total number of insects tested. $*$, significant difference $(P<0.05)$ using chi-square test comparing untreated control versus $P$. syringae treatment. ${ }^{* *}$, significant difference $(P<0.001)$ using chi-square test comparing untreated control versus $P$. syringae treatment.

ble 2). However, two species had high levels of mortality; only $43 \%$ of the C. pusillus adults and $19 \%$ of $T$. castaneum adults survived. At $-8^{\circ} \mathrm{C}$, the control groups of three species exhibited survival rates of $\geq 77 \%$ (Table 3 ). No individuals of C. pusillus, T. castaneum, or $R$. dominica survived a $24-\mathrm{h}$ exposure to $-8^{\circ} \mathrm{C}$.

Application of 100 or $1,000 \mathrm{ppm}$ of $P$. syringae in wheat decreased survival for all eight species tested at $-5^{\circ} \mathrm{C}$ (Table 1). For two species, $C$. ferrugineus and $R$. dominica, the application of $100 \mathrm{ppm}$ reduced survival from $\geq 90 \%$ in the control group to $<5 \%$. In five species, no individual survived exposure to $-8^{\circ} \mathrm{C}$ after treatment with $1,000 \mathrm{ppm}$ of $P$. syringae. In the granary weevil, survival decreased from 96 to $48 \%$. Larvae of $T$. molitor were the most resistant species to $P$. syringae, with $53 \%$ survival after treatment with $1,000 \mathrm{ppm}$.

All five species in which $\geq 50 \%$ of individuals in the control group survived at $-8^{\circ} \mathrm{C}$ exhibited a statistically significant decrease in survival after treatment with 100 or 1,000 ppm (or both) concentrations of $P$. syringae (Table 2). Furthermore, in four of these five species (S. granarius, C. ferrugineus, P. interpunctella, and G. psylloides), treatment with $1,000 \mathrm{ppm}$ of $P$. syringae

Table 3. Survival of adult stored grain pests exposed to various concentrations of dry, powdered $P$. syringae in corn for $24 \mathrm{~h}$ at $23^{\circ} \mathrm{C}$ before 24 -h exposure to $-8^{\circ} \mathrm{C}$

\begin{tabular}{|c|c|c|c|}
\hline \multicolumn{4}{|c|}{$\%$ Survival } \\
\hline \multirow[b]{2}{*}{ Species } & \multirow{2}{*}{$\begin{array}{c}\text { Untreated } \\
\text { Control }\end{array}$} & \multicolumn{2}{|c|}{ P. syringae } \\
\hline & & $100 \mathrm{ppm}$ & $\begin{array}{l}1,000 \\
\mathrm{ppm}\end{array}$ \\
\hline S. granarius (adults) & $73(22 / 30)$ & $23(7 / 30)^{*}$ & $0(0 / 30)^{*}$ \\
\hline C. ferrugineus (adults) & $83(25 / 30)$ & $0(0 / 30)^{*}$ & $0(0 / 30)^{*}$ \\
\hline
\end{tabular}

Survival was assessed after a $24-\mathrm{h}$ recovery period at $23^{\circ} \mathrm{C}$. Numbers in parenthesis indicate the number of survivors/tota number of insects tested. ${ }^{*}$, significant difference $(P<0.001)$ using chi-square test comparing untreated control versus $P$ syringae treatment. reduced survival rates to $\leq 4 \%$ after exposure to $-8^{\circ} \mathrm{C}$.

In another experiment, corn was substituted for wheat and the effect of $P$. syringae on low temperature survival was tested (Table 3). Again treatment with $100 \mathrm{ppm} P$. syringae caused a significant decrease $(P<0.001)$ in survival following exposure to $-8^{\circ} \mathrm{C}$. In the rusty grain beetle, all adults died after treatment with 100 ppm, whereas no granary weevils survived exposure to $1,000 \mathrm{ppm}$.

\section{Discussion}

The use of low temperatures to control insects in stored grain is not a new idea: a significant number of studies including Knipling \& Sullivan (1957), Smith (1970), Mullen \& Arbogast (1979), Hunter \& Taylor (1980), and Johnson \& Wofford (1991) have investigated this approach for pest control in stored products. Our strategy for control differs from previous ones in that we propose to manipulate natural mechanisms of insects for freeze avoidance to make them more susceptible to cold exposure. We have shown that treatment with $P$. syringae significantly increased the supercooling point of stored-grain insects. Because these species are intolerant of freezing, an elevation of the supercooling point represents a decrease in their cold tolerance. Reduced cold tolerance was also demonstrated for insects exposed to subzero temperatures for $24 \mathrm{~h}$.

The use of ice-nucleating active bacteria as biological insecticides requires that bacterial application occur concurrently with the exposure of insects to temperatures at or below the supercooling point. Although insects used in this study were not cold acclimated, other data indicate that ice-nucleating active bacteria are effective in increasing the supercooling point of cold-hardy insects including $C$. ferrugineus (Fields 1991), Hippodamia convergens GuérinMéneville (Lee et al. 1991), and Ceratoma tri- 
furcata (Forster) (unpublished data). Advantages of this biological insecticide are that it is biodegradable and its use is compatible with other control measures used in integrated pest management programs. In fact, bacterial application would occur during the winter months when other forms of control are not used.

The development of insect resistance to chemical control is well known. Insects may be slower to develop resistance to ice-nucleating active bacteria than to chemicals, because of the physical as opposed to biological nature of the mechanism by which they decrease cold-hardiness. These bacteria function as ice catalysts that limit the supercooling capacity of insect body water, causing it to freeze at temperatures only a few degrees $<0^{\circ} \mathrm{C}$. Even in insects with mouths that were sealed to prevent bacterial ingestion, supercooling points were elevated within minutes after topical application (unpublished data). Although, at this time, we do not know the route (e.g., spiracles, anus, pores in the cuticle) by which bacteria come in contact with insect body water, the supercooling point is elevated very rapidly, suggesting the absence of effective barriers to block ice nucleation. Consequently, it may be difficult to develop resistance because it would require the blocking of all avenues of contact between the bacteria and internal water. Thus, development of physiological mechanisms of resistance to bacterial ice nucleation may be a more complex and unlikely process compared with mechanisms of chemical resistance.

\section{Acknowledgment}

We thank George Keeney (Department of Entomology, Ohio State University) and Esther Fleming (Department of Entomology, Kansas State University) for providing us with starter insect cultures. Paul Fields generously provided us with an advance copy of a manuscript in press and reviewed a draft of this paper. Jon Costanzo assisted with the statistical analysis. $\mathrm{Ge}$ nencor International, Rochester, New York, and NSF grant DCB-88113117 provided support for this project.

\section{References Cited}

Bell, C. H. 1982. Observations on the intensity of diapause and cold tolerance in larvae from twelve populations and two reciprocal crosses of the Indianmeal moth, Plodia interpunctella. Physiol. Entomol. 7: 371-377.

Baust, J. G. \& R. R. Rojas. 1985. Review-Insect cold hardiness: facts and fancy. J. Insect Physiol. 31: 755-759.

Evans, D. E. 1983. The influence of relative humidity and thermal acclimation on the survival of adult grain beetles in cooled grains. J. Stored Prod. Res. 19: 173-180.
Fields, P. G. 1991. The cold-hardiness of Cryptolestes ferrugineus and the use of ice nucleationactive bacteria as a cold synergist. Proceedings 5th International Working Conference Stored-Product Protection, Bordeaux, France (in press).

Hunter, A. J. \& P. A. Taylor. 1980 . Refrigerated aeration for the preservation of bulk grain. J. Stored Prod. Res. 16: 123-131.

Johnson, J. A. \& P. L. Wofford. 1991. Effects of age on response of eggs of Indianmeal moth and navel orangeworm (Lepidoptera: Pyralidae) to subfreezing temperatures. J. Econ. Entomol. 84: 202-205.

Knipling, E. B. \& W. N. Sullivan. 1957. Insect mortality at low temperature. Science 50: 368-369.

Lee, R. E. 1989. Insect cold-hardiness: To freeze or not to freeze. BioScience 39: 308-313.

1991. Principles of insect low temperature tolerance, pp. 17-46. In Insects at Low Temperature, R. E. Lee \& D. L. Denlinger (eds.) Chapman \& Hall, New York.

Lee, R. E. \& D. L. Denlinger (eds.) 1991. Insects at low temperature. Chapman and Hall, New York.

Lee, R. E., J. M. Strong-Gunderson, M. R. Lee, K. S. Grove \& T. J. Riga. 1991. Isolation of ice nucleating active bacteria from insects. J. Exp. Zool. 257: 124-127.

Lindow, S. E. 1983. The role of bacterial ice nucleation in frost injury to plants. Annu. Rev. Phytopathol. 21: 363-384.

Mullen, M. A. \& R. T. Arbogast. 1979. Timetemperature-mortality relationships for various stored-product insect eggs and chilling times for selected commodities. J. Econ. Entomol. 72: 476478.

Ring, R. A. 1982. Freezing-tolerant insects with low supercooling points. Comp. Biochem. Physiol. 73A: 605-612.

Shimada, K. 1989. Ice-nucleating activity in the alimentary canal of the freezing-tolerant prepupae of Trichiocampus populi (Hymenoptera: Tenthredinidae). J. Insect Physiol. 53: 113-120.

Smith, L. B. 1970. Effects of cold-acclimation on supercooling and survival of the rusty grain beetle, Cryptolestes ferrugineus (Stephens) (Coleoptera: Cucujidae), at subzero temperatures. Can. J. Zool. 48: 853-858.

Sokal, R. R. \& F. J. Rohlf. 1973 . Introduction to Biostatistics. Freeman, San Francisco.

Somme, L. 1982. Supercooling and winter survival in terrestrial arthropods. Comp. Biochem. Physiol. 73A: 519-543.

Strong-Gunderson, J. M., R. E. Lee \& M. R. Lee. 1989. Ice nucleating bacteria promote transcuticular nucleation in insects. Cryobiology 26: 551 .

Strong-Gunderson, J. M., R. E. Lee, M. R. Lee \& T. J. Riga. 1990. Ingestion of ice nucleating active bacteria increases the supercooling point of the lady beetle Hippodamia convergens. J. Insect Physiol. 36: 153-157.

Received for publication 10 May 1991; accepted 25 November 1991. 